Revue d'études américaines. American Studies Journal

$2 \mid 2017$

(Hi)stories of American Women: Writings and Rewritings / Call and Answer: Dialoguing the American West in France

\title{
Introduction: (Hi)stories of American Women: Writings and Re-writings
}

\section{Anne Stefani}

\section{QpenEdition \\ Journals}

\section{Electronic version}

URL: https://journals.openedition.org/transatlantica/10045

DOI: 10.4000/transatlantica.10045

ISSN: $1765-2766$

Publisher

Association française d'Etudes Américaines (AFEA)

\section{Electronic reference}

Anne Stefani, "Introduction: (Hi)stories of American Women: Writings and Re-writings", Transatlantica [Online], 2 | 2017, Online since 22 May 2019, connection on 01 February 2023. URL: http://

journals.openedition.org/transatlantica/10045 ; DOI: https://doi.org/10.4000/transatlantica.10045

This text was automatically generated on 1 February 2023.

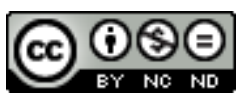

Creative Commons - Attribution-NonCommercial-NoDerivatives 4.0 International - CC BY-NC-ND 4.0 https://creativecommons.org/licenses/by-nc-nd/4.0/ 


\title{
Introduction: (Hi)stories of American Women: Writings and Re- writings
}

\author{
Anne Stefani
}

1 After more than four decades of development in the United States and elsewhere, women's and gender history has become a recognized academic field, and continues to engage scholars and the general public in several interpretive debates on the status of women in American society (Dayton and Levenstein; Thébaud; Pfefferkorn). Such debates are fueled by contemporary social and cultural trends-particularly the crisis of democracy and the evolution of power relations in connection with the influence of social media, the persistent prevalence of race in politics, the redefinition of minorities and multiculturalism, or the renewed controversies over victimization and agency. In the first stages of its development, in the late 1960s and early 1970s, the primary goal of women's history was to make women visible in a historical narrative dominated by and centered on white men. After the pioneering works of William Chafe, Gerda Lerner and Paula Giddins, the trend has continued to this day. ${ }^{1}$ The titles of some publications are strikingly explicit about the issue of invisibility (Barnett; Browning; Frear; Sartain; Scott). The following stage, in the 1980s and 1990s, consisted in reexamining categories by taking into account the influence of social, economic, and political factors in the shaping of individual identities-with a growing emphasis on class and race. It was in this second stage that the redefinition of sex and race as constructs complicated the interpretive frame by insisting on the diversity of female experiences, warning against the pitfalls of essentialism (Janiewski; Spelman; Collins; Jones; Ruiz). From the 1990s on, scholars and commentators insisted on the importance of using a greater range of sources; focusing on different groups; and using a diversity of scales: local, regional, and global. ${ }^{2}$ The key concepts that came to the fore in this process-such as agency, empowerment, and intersectionality-have become central to any discussion of women and gender in American history, the landmark publication in that respect being Kimberlé Crenshaw's 1989 article, "Demarginalizing the Intersection of Race and Sex" (Crenshaw; Nash). 
2 The following collection of articles is a contribution to the ongoing reflection on the place and role of women in the construction, deconstruction, and reconstruction, of their stories and experiences through American history, past and present. The growth of women's history, and more generally women's and gender studies, since the 1970s, is obviously related to the social and cultural developments of the 1960s and early 1970s. It cannot be dissociated from the social movements that literally brought it forth, the black liberation movements, the New Left, and the so-called second wave of feminism (Evans). These movements deeply transformed mainstream popular and academic cultures in the United States. By successfully challenging the hegemony of white men in society and culture, they created the conditions for a redefinition of power relations and a reconstruction of the national historical narrative. They had a profound and lasting impact on historiography in all fields, as is best illustrated by the rise of history from the bottom up, as early as the 1970s (Zinn). Such a process made it necessary to include in the narrative populations that had thus far been ignored, but also to change the way these groups were represented, and this ultimately transformed the balance of power in society. The issue of representation is indeed central to the study of women's and gender history insofar as women's invisibility in history was not only due to their subordinate social status, but also to the cultural and academic norms sustaining such status (Perrot 11-19).

3 The following articles explore very different subjects in various historical contexts, from the nineteenth to the twenty-first centuries. Yet, they all share a common theme: the impact of cultural, social, and political standards on women's experiences and their responses to the imposition of norms throughout history. These essays in women's and gender history also belong to the larger field of cultural history, especially when considering the nature of the sources used: several authors (Hélène Le Dantec-Lowry, Jane Bayly, and Cristelle Maury) ground their reflection in visual culture (from advertising posters to photography and cinema), while others (Élise Vallier and Joan C. Browning) examine personal writings, either through private/intimate sources (such as diaries and correspondence) or published memoirs and autobiographies. ${ }^{3}$ Three authors (Vallier, Bayly, and Browning) focus on sources created by women. The other two (Le Dantec-Lowry and Maury) discuss representations of women constructed by others.

With this diversity of perspectives and approaches, these essays all examine the dialectical tension between the norms and representations imposed onto women through history, on the one hand, and the various forms of responses by women and feminists (both male and female) that range from compliance to explicit resistance, on the other. Since women were long confined to the so-called private sphere and, when involved in public organizations, were virtually excluded from positions of leadership, they left very little evidence of their contribution to history in official, institutional, and other public documents. Hence the interest of scholars for other sources through which women expressed themselves and, in many cases, told their own stories (Thébaud 71-78).

5 The rewriting and reinterpretation of women's history in light of new sources cannot be disconnected from the societal debates that shape American politics. Scholarly issues cannot be considered separately from the feminist movements that have periodically challenged the social and cultural norms imposed onto women and ethnic, racial, and sexual minorities. Scholarship on women thus participates in a process of 
rewriting initiated by women's own struggle for cultural self-assertion and recognition. Like other social categories long ignored by both mainstream culture and academia (ethnic, racial, sexual, gender, and class minorities among others), women have come to tell their own stories as a counter-narrative to the dominant history-be it in print (Kerber et al.; Rugg, and Willis) or other media, such as photography (Brunet 2017). Scholars have also enriched the narrative by demonstrating the value of sources long dismissed or ignored by historians on account of their being the unreliable products of scattered individual subjectivities, and by reinterpreting women's history from official, largely male-authored sources. In the process, they have helped in the expression of neglected contemporary voices; they have also unearthed unsuspected earlier voices, testifying to the existence of many forms of female self-expression. These developments, however, should not lead us to think that all work by and about women is inherently feminist. If the impact of feminism and feminist theory on all contemporary works is undeniable, women telling their own stories or scholars studying women's experiences do not necessarily embrace a feminist perspective. That being said, the mere fact of choosing women as a writing subject or making women's voices heard and reflecting on their experiences, can be considered a feminist undertaking in itself, as a conscious form of self-assertion.

6 The five essays presented in this issue explore the writing and rewriting of women's and gender history by analyzing both the effect of cultural norms on women's lives and self-representations, and the impact of women's intervention on the society in which they live. Taken together, the following essays illuminate the evolution of women's representations in history; they also discuss how women seek to re-appropriate their lives by producing their own stories. The various modes of expression (diaries, correspondence, autobiography, visual arts) serve many functions in the counternarrative women have opposed to the master narrative: filling in blanks, correcting inaccuracies, asserting women's agency, enriching and nuancing the collective narrative, and transmitting women's experiences to the younger generation.

7 The first four scholarly articles are arranged chronologically to set the common theme of women's representations firmly in historical perspective. The first two-"African American Womanhood: A Study of Women's Life Writings (1861-1910s)" and "To Speed Our Boys Home... Produce and Conserve. Share and Play Square. Home Front Propaganda and Food during World War II: Rewriting Gender?"-deal with periods prior to the 1960s-1970s feminist movements (the turn of the nineteenth century and World War Two). The third and fourth essays-"Re-representing 'The Great American Institution that Never Gets Mentioned on the Fourth of July': Engaging (Feminist) Theories in Todd Haynes's miniseries Mildred Pierce (HBO, 2011)" and "A Day in the Life of the American Woman: Construction and Mediation of the 'American Woman' in Photographic Essays"-focus on the twenty-first century, thus assessing the double impact of context and feminism on women and their (self)-representations.

8 Following a special contribution by Joan C. Browning that is presented below, the scholarly dossier opens with Élise Vallier's prosopographical study of African American women between the Civil War and the 1920s. She examines the various conditions of black women (both northern and southern) through a sample of seven cases. After identifying the social and cultural constraints shaping the lives of these women (especially race, class, gender, and regional norms), she analyzes their individual responses through different forms of self-writing. One of the many interests of this 
article is to reflect on the use of intimate sources and life narratives as historical documents. By giving us access to the private, inner experiences of the women she studies, Vallier not only makes them visible, but, more importantly, she demonstrates how they negotiated with constraining norms by writing diaries, letters, memoirs, and autobiographies. Vallier thus assesses her subjects' successes and failures by exploring the way they internalized the dominant norms and (re)constructed their identities through self-representation.

9 The second scholarly article analyzes a specific instance of patriarchal oppression by focusing on governmental propaganda during World War Two. Hélène Le Dantec-Lowry examines the visual representations of women at the time, by concentrating on posters and booklets issued by the federal government, together with advertisements and cookbooks. She demonstrates how traditional gender, class, and ethnoracial stereotypes were adjusted to the specific wartime context so as to encourage women to participate in the collective war effort, while creating a representation that was to help maintain them in a domestic role in the 1950s. The study of visual sources here illuminates the contradictions between the government's discourse and the underlying message conveyed by images. Le Dantec-Lowry broadens our knowledge of American women's history by studying cookbooks. While these documents were neglected by historians until quite recently, understanding how they were adapted to World War Two propaganda offers a welcome insight into American homes-specifically gender roles within the American family at mid-twentieth century-and the way women negotiated imposed norms. This approach furthers our understanding of the following periods, particularly the 1960s and the emergence of second-wave feminism.

The third scholarly article mainly concentrates on a work created in the twenty-first century: Mildred Pierce, a television mini-series by Todd Haynes. It is nevertheless connected to the previous essay through its secondary focus, i.e. two other works created during World War Two. Cristelle Maury analyzes three versions of the same story: the original novel by James Cain published in 1941, a movie adaptation released in 1945, and a second adaptation-Todd Haynes's-released in 2011. This article explores the evolution of various fictional representations of women and women's work before and after second- and third-wave feminisms. By focusing primarily on the adaptation by Todd Haynes, who identifies publicly as a queer filmmaker, Maury analyzes the influence of feminism and feminist theory on artistic creation. This multilayered essay convincingly discusses the interconnection between artistic works and their context of production through the treatment of women's representations. It shows more particularly how the most recent version of Mildred Pierce is informed by intersectional theory, while the earlier versions deal with representations of women echoing the 1940s propaganda studied by Hélène Le Dantec-Lowry. Cristelle Maury's article thus provides a forceful demonstration of the impact of contemporary feminism on popular culture.

11 The fourth and last scholarly article in this collection also explores the impact of feminism on twenty-first century representations of women. In her study of A Day in the Life of the American Woman, a photo-book published in 2005, Jane Bayly examines the collective construction of the "American Woman" by fifty women photographers. This article, like the previous two, reflects on the evolution of women's representations in history through the prism of visual culture. A close analysis of the photographs and texts collected in the book allows Bayly to address the ambivalent legacy of feminism in 
today's American culture. She sheds light on a paradox by revealing a discrepancy between the book's proclaimed intent and its actual representation of American women. Bayly shows first that the book stands as one more contribution to the reappropriation of women's history by women themselves, in keeping with the latest trends in the nation's cultural evolution. Second, she argues that this collective selfportrait ultimately fell short of its aim in that it remains dependent on traditional stereotypes that are still ingrained in contemporary culture. Bayly thus points out limits in women's re-appropriation of their identities through the writing of their own (hi)stories.

The first article in this dossier stands apart from the others and deserves special attention. Its author, Joan C. Browning, is not a scholar but a veteran of the 1960s nonviolent Civil Rights Movement in the South. A white woman born in 1942 in rural Georgia and raised in a white supremacist milieu, she repudiated her segregationist education during her college years, participated in direct action campaigns against segregation in the early 1960s, and dedicated the rest of her life to the fight for racial and social justice. In 2000, she was a leading contributor to Deep in Our Hearts, a collection of autobiographical essays by nine white women who had participated in what they and other activists named the Freedom Movement. Browning is thus a living embodiment of the very subject matter in this thematic dossier. Her essay is a personal reflection on the writing of her story for Deep in Our Hearts. Interestingly, although she does not define herself primarily by her gender-and certainly does not adopt a feminist outlook-Browning does discuss the implications of her being a woman in her experience of the 1960s movement and after. Her testimony thus corroborates many findings and interpretations discussed in the four scholarly articles presented above, while raising other epistemological questions related to the self-writing process: the specificity of autobiographical sources as historical material, the invisibility of women in historiography, the relevance of subjectivity to historical interpretation, the challenge of factual accuracy, the tension between private and public life, and between the personal and the political. Most importantly, Browning's contribution is a mise en abyme of the scholarly reflection on the writing and rewriting of American women's history that this dossier aims to present. It is a powerful and moving example of women's re-appropriation of their history today. Browning, a major historical actor, not only deepens the narrative by re-telling-and updating-her story, but she also ponders over the meaning of her experience as a white southern anti-racist activist and a woman. Given the hybrid status of this article-both primary source and reflexive essay on our theme-the editors have chosen to place it first to open the discussion on women's experiences and representations in American history. 


\section{BIBLIOGRAPHY}

BARNETT, Bernice McNair. "Invisible Southern Black Women Leaders in the Civil Rights Movement: The Triple Constraints of Gender, Race, and Class." Gender and Society, vol. 7, no. 2, 1993, p. 162-182.

BARBRE, Joy Webster, et al. (The Personal Narratives Group). Interpreting Women's Lives: Feminist Theory and Personal Narratives. Bloomington: Indiana University Press, 1989.

BROQUA, Vincent, and Guillaume MARCHE, eds. L'Épuisement du biographique ? Newcastle upon Tyne: Cambridge Scholars, 2010

BROWNING, Joan C. "Invisible Revolutionaries: White Women in Civil Rights Historiography." Journal of Women's History, vol. 8, no. 3, 1996, p. 186-204.

BRUNET François. “(Re)defining Visual Studies.” InMedia, no. 3 | 2013, journals.openedition.org/ inmedia/543. Accessed March 29, 2019.

---. La photographie, histoire et contre-histoire. Paris: Presses Universitaires de France, 2017.

CHAFE, William H. The American Woman: Her Changing Social, Economic and Political Role, 1920-1970. New York: Oxford University Press, 1972.

CRAWFORD, Vicki L., Jacqueline ROUSE, and Barbara WOODS, eds. Women in the Civil Rights Movement: Trailblazers and Torchbearers, 1941-1965. Brooklyn: Carlson, 1990.

CRENSHAW, Kimberlé W. "Demarginalizing the Intersection of Race and Sex: A Black Feminist Critique of Antidiscrimination Doctrine, Feminist Theory and Antiracist Politics." University of Chicago Legal Forum, no. 1, 1989, p. 139-168.

DAYTON, Cornelia H., and Lisa LEVENSTEIN. "The Big Tent of US Women's and Gender History: A State of the Field." Journal of Southern History, vol. 99, no. 3, 2012, p. 793-817.

DOSSE, François. Le pari biographique, écrire une vie. Paris: La Découverte, 2005.

EVANS, Sara M. Personal Politics: The Roots of Women's Liberation in the Civil Rights Movement and the New Left. New York: Knopf, 1979.

FREAR, Yvonne Davis. "Making the Invisible Visible: African American Women in the Texas Civil Rights Movement." Southern Black Women in the Modern Civil Rights Movement. Eds. Yvonne Davis Frear and Bruce A. Glasrud. College Station: Texas A\&M University Press, 2013, p. 29-43.

FRYSTAK, Shannon. Our Minds on Freedom: Women and the Struggle for Black Equality in Louisiana, 1924-1967. Baton Rouge: Louisiana State University Press, 2009.

GIDDINGS, Paula J. When and Where I Enter: The Impact of Black Women on Race and Sex in America. New York: Quill/W. Morrow, 1984.

HILL COLLINS, Patricia. Black Feminist Thought: Knowledge, Consciousness, and the Politics of Empowerment. Boston: Unwin Hyman, 1990.

JANIEWSKI, Dolores. Sisterhood Denied: Race, Gender, and Class in a New South Community. Philadelphia: Temple University Press, 1985.

JONES, Jacqueline. Labor of Love, Labor of Sorrow: Black Women, Work, and the Family from Slavery to the Present. 1985. New York: Vintage, 1986.

KERBER, Linda. Women's America: Refocusing the Past. 1982. Oxford: Oxford University Press, 2016. 
LERNER, Gerda. The Majority Finds Its Past: Placing Women in History. New York: Oxford University Press, 1979.

MAYNES, Mary Jo, Jennifer L. PIERCE, and Barbara LASLETT. Telling Stories: The Use of Personal Narratives in the Social Sciences and History. Ithaca: Cornell University Press, 2008.

NASH, Jennifer C. “Re-thinking Intersectionality.” Feminist Review, no. 89, 2008, p. 1-15.

OFFEN, Karen M., Ruth Roach PIERSON, and Jane RENDALL, eds. Writing Women's History: International Perspectives. Bloomington: Indiana University Press, 1991.

OLSON, Lynne. Freedom's Daughters: The Unsung Heroines of the Civil Rights Movement. New York: Simon and Schuster, 2001.

PERROT, Michelle. Les Femmes ou les silences de l'histoire. Paris: Flammarion, 2001.

PFEFFERKORN, Roland. Inégalités et rapports sociaux. Rapports de classes, rapports de sexe. Paris: La Dispute, 2007.

POPKIN, Jeremy D. History, Historians, and Autobiography. Chicago: University of Chicago Press, 2005.

RUGG, Linda Haverty. Picturing Ourselves: Photography and Autobiography. Chicago: University of Chicago Press, 1997.

RUIZ, Vicki L. From Out of the Shadows: Mexican Women in Twentieth-Century America. New York: Oxford University Press, 1998.

SARTAIN, Lee. Invisible Activists: Women of the Louisiana NAACP and the Struggle for Civil Rights, 1915-1945. Baton Rouge: Louisiana State University Press, 2007.

SCOTT, Anne Firor. Making the Invisible Woman Visible. Urbana: University of Illinois Press, 1984.

---. "Most Invisible of All: Black Women's Voluntary Associations." Journal of Southern History, vol. 56, no. 1, 1990, p. 3-22.

SPELMAN, Elizabeth V. Inessential Woman: Problems of Exclusion in Feminist Thought. Boston: Beacon Press, 1988.

STEFANI, Anne. Unlikely Dissenters: White Southern Women in the Fight for Racial Justice. Gainesville: University Press of Florida, 2015.

THÉBAUD, Françoise. Écrire l'histoire des femmes et du genre. Paris: ENS Éditions, 2007.

WILLIS, Deborah. Picturing Us: African American Identity in Photography. New York: New Press, 1994.

ZINN, Howard. A People's History of the United States. New York: Longman, 1980.

\section{NOTES}

1. See for instance, among many others: Scott; Crawford et al.; Olson.

2. See for instance: Frystack and Stefani (regional scale); Offen et al. (global scale).

3. On the growing importance of visual culture in the re-writing of history, see for instance Brunet 2013. On the use of autobiographical sources as documents, see for instance Maynes et al., and Popkin. On the biographical genre see also Broqua and Marche; Barbre et al.; and Dosse. 


\section{AUTHOR}

\section{ANNE STEFANI}

Université Toulouse Jean-Jaurès 